EDWARD III 


\section{Also in the Yale English Monarchs Series}

AETHELSTAN: THE FIRST KING OF ENGLAND by Sarah Foot EDWARD THE CONFESSOR by Frank Barlow

WILLIAM THE GONQUEROR by David Douglas*

WILLIAM REFUS by Frank Barlow

HENRY I by Warren Hollister

KING STEPHEN by Edmund King

HENRY II by W. L. Warren*

RICHARD I by John Gillingham

KING JOHN by W. L. Warren*

EDWARD I by Michael Prestwich

EDWARD II by Seymour Phillips

RICHARD II by Nigel Saul

HENRY V by Christopher Allmand

HENRY VI by Bertram Wolffe

EDWARD IV by Charles Ross

RICHARD III by Charles Ross

HENRY VII by S. B. Chrimes

HENRY VIII by J. J. Scarisbrick

MARY I by John Edwards

EDWARD VI by Jennifer Loach

JAMES II by John Miller

QUEEN ANNE by Edward Gregg

GEORGE I by Ragnhild Hatton

GEORGE II by Andrew C. Thompson

GEORGE III by Jeremy Black

GEORGE IV by E. A. Smith

* Available in the U.S. from University of California Press 


\section{EDWARD III}

W. Mark Ormrod

YALE UNIVERSITY PRESS

NEW HAVEN AND LONDON 


\section{Copyright (C) 20I I W. Mark Ormrod}

All rights reserved. This book may not be reproduced in whole or in part, in any form (beyond that copying permitted by Sections I07 and Io8 of the U.S. Copyright Law and except by reviewers for the public press) without written permission from the publishers.

For information about this and other Yale University Press publications, please contact: U.S. Office: sales.press@yale.edu_www.yalebooks.com

Europe Office: sales@yaleup.co.uk_www.yalebooks.co.uk

Set in Baskerville by IDSUK (DataConnection) Ltd

Printed in Great Britain by TJ International Ltd, Padstow, Cornwall.

Library of Congress Cataloging-in-Publication Data

Ormrod, W. M., I957-

Edward III/W. Mark Ormrod. p. cm.

Includes bibliographical references and index.

ISBN 978-0-300-I I9I0-7 (cl:alk. paper)

I. Edward III, King of England, I312-I377. 2. Great Britain-History-Edward III, I327-I377. 3. Great Britain-Kings and rulers - Biography. 4. Great Britain-Politics and government $-\mathrm{I} 327^{-} \mathrm{I} 377$. I. Title.

DA233. ${ }_{737} 2012$

$942.03^{\prime} 7092-\mathrm{dc} 22$

[B]

2011013536

A catalogue record for this book is available from the British Library.

IO 98765432 I 
For Richard 
